\title{
THE CATHOLIC CHURCH IN THE PHILIPPINE PUBLIC SPHERE'
}

\author{
Ranilo B. Hermida \\ Department of Philosophy \\ Ateneo de Manila University \\ rhermida@ateneo.edu
}

\begin{abstract}
Whether religion has a place in the public sphere is a complex issue. Many thinkers believed that the rationalization process of modernity would result in secularization and banish religion into the private sphere. Religion has not only survived; it has even taken an active role in the political affairs of the state. This has been the case in countries like the Philippines where the publicity and activism of the Catholic hierarchy in the political public sphere of the country have been sustained and to some extent dominant. Said publicity and activism are carried out in the name of religion and the pursuit of a religious mandate accordingly. Although the reactions to such public involvement have not always been the same, these varying reactions still make sense in light of some theoretical understanding about the specifically political role of religion in the modern society. The aim of this paper is to make a modest contribution to such understanding by reflecting on the place and function of religion in the public sphere. It trains a special focus on the Philippine experience and employs mainly the view of Jürgen Habermas, an "agnostic and secular thinker" but one who has written extensively on the public sphere and recently revised his stance from thinking that religion will be overtaken by the rationalization of society to admitting that religion has something important to contribute in the public sphere.
\end{abstract}

\section{Keywords}

Catholic Bishops Conference of the Philippines, critical theory, democracy, law, people power revolution, reproductive health law

\section{About the Author}

Ranilo B. Hermida is Associate Professor of Philosophy at the Ateneo de Manila University in the Philippines and is Associate Editor of Budhi: Journal of Ideas and Culture. He received his doctorate in philosophy from Monash University in Australia. He has published articles in national and international journals, and delivered papers in national and international conferences. He is the author of the newly released book, Imagining Modern Democracy: A Habermasian Assessment of the Philippine Experiment (State University of New York Press, 2014). 


\section{SITUATING RELIGION IN THE PUBLIC SPHERE}

That religion does have a place in the public sphere may seem to be a given proposition. Such a place for religion, however, was not always acknowledged. At the dawn of modernity religion became the subject of contestation among theorists who predicted that "the only remains of religion may be a totally privatized experience of it by a few" (Dreyer and Pieterse 1).

Habermas himself did not always reckon a legitimate place for religion in the modern society. At first he adopted the view suspecting religion as a cause of social alienation and therefore had to be overcome. He next revised his position by campaigning for its "privatization" after realizing that religion did not wither away as expected. He then advocated that religious convictions should remain outside the public domain. The current view that he espouses is a reversion of his previous advocacy. In his more recent works, The Future of Human Nature (2003) and Between Naturalism and Religion (2008), Habermas now maintains that "religion should not be limited to the private sphere" and that "it should intervene in the public sphere and use its founding documents and traditions to refine 'moral intuitions"' (Portier 426). This last stance of Habermas (2008), while welcome in some quarters, has not been spared of criticism in others. This is so even among those who take his position as favorable to their own affirmative stance on the place of religion in the public sphere. One major bone of contention is his insistence on a "translation imperative" by which he meant that religious institutions must employ the public use of reason and their religious insights be expressed in a "publicly intelligible language" (Between Naturalism and Religion 113) when engaging in the public sphere. Critics of his view argue that the translation imperative extracts the religious insights from their proper context and thereby diminishes their full significance.

The focus of this paper is not on the recent works of Habermas mentioned above and the debate surrounding his view about the putatively acceptable participation of religion in the public sphere. It is rather on a much earlier theory of law and democracy which he elaborated in Between Facts and Norms where he discusses at length how the public sphere stands as an essential periphery to the formal machinery of government insuring the democratic character of the latter's administrative operations and legislative enactments.

\section{THE CATHOLIC CHURCH IN PHILIPPINE SOCIETY}

The important part that religion has played in Philippine society dates back to the time when the country was just beginning to develop a "political and social identity." Steven Shirley notes: 
A common national identity did not exist in the Philippines prior to the arrival of organized religion. Indeed, the idea of what it meant to be "Filipino" did not exist prior to the Spanish arrival in 1521 and the introduction to Catholicism. Based on the anthropological and cultural studies on the pre-Spanish Philippines, it is believed that there was no singular "nation" in the Philippines, and no concept of being "Filipino." This situation existed in part due to the geographical layout of the archipelago, and it also resulted from the lack of commonality in laws, norms, and values among the various tribal groups that were themselves the result of centuries of human migrational waves into the islands. (5)

The important role of Islam should be mentioned as well. Shirley highlights the fact that it was the unifying element in Islam, "its monotheistic doctrine and strong tendency to organize society around a moralistic body of laws" that "gave the small, fragmented tribal communities throughout the Philippines their first conception of 'organized' civilization, coupled with a communal identity that went further than the local barangay" (Shirley 7,8 ).

Since then religion, more specifically the Catholic Church, has occupied a central place in Philippine society throughout its history. The involvement of the Church was initially and for the most part in community organizing and development and in citizen movements. What triggered its political engagement was a series of events beginning on December 8, 1965 when the Second Vatican Council concluded with a "strong legitimation for religious concerns with social issues" (Carroll 114). The response of the Philippine Catholic hierarchy was immediate and consisted of several initiatives. At about the same time, liberation theology began to spread around the world and attracted members of the Philippine clergy. In 1973, Fr. Edicio de la Torre founded Christians for National Liberation which soon went underground after some of its priest-members were arrested by the military. The official hierarchy did not engage the Marcos dictatorship in open confrontation but, through its diocesan social action centers, "provided institutional support to popular organization initiatives designed to challenge the local hegemony of landlords, and its enforcer, the military or private armies" (Clarke 235-237).

The most dramatic and crucial involvement of Church leaders in the political affairs of the country is underscored by the premier role that the late Jaime Cardinal Sin, Archbishop of Manila, played in the successful people power revolution of 1986 which toppled the Marcos dictatorship in a peaceful and non-violent manner, and restored democracy in the country. It must be recalled that "it was largely due to [the] massive political pressure exerted by the Church" (Shirley 71) that Marcos announced in 1985 a snap presidential election to be held the next year. The election was marred by violence, as well as staggering and blatant election fraud, targeted against the opposition (Burton 350-353, 356-357). The Catholic 
Bishops' Conference of the Philippines (CBCP) came out with a denunciation of the election describing it "unparalleled in the fraudulence of [its] conduct" ("Post-Election Statement").

When the planned coup d'etat of the Reform the Armed Forces Movement was discovered, then Defense Minister, Juan Ponce Enrile, and Vice Chief of Staff, Fidel Ramos, who both supported the coup plotters called on Cardinal Sin to ask for help after having established their battle position at Camp Aguinaldo against the military forces that remained loyal to Marcos. Lucy Komisar recounts that in their phone conversation Enrile told Sin, "I will be dead within one hour... I don't want to die... if possible do something" (105). Ramos also talked to Sin asking the latter to call on the people to help them. Accordingly the Cardinal pledged his support assuring them both that "in fifteen minutes, your place will be filled with people" (105).

It was the evening of February 22, 1986 when Cardinal Sin spoke on the Catholic station Radio Veritas to appeal to the nation to support Enrile and Ramos by congregating along Epifanio de los Santos Avenue (EDSA) fronting Camp Aguinaldo. "Our two good friends have shown their idealism," Sin told the radio listeners, "I would be very happy if you could support them now." The call was effective and in a few hours some twenty thousand civilians had massed outside the camp on EDSA (Burton 387-388). ${ }^{3}$

Marcos decided not to confront the coup plotters at once claiming a policy of "maximum tolerance." The first "loyalist" tanks, led by a hesitant Marine Commandant, Brig. Gen. Artemio Tadiar, made their way to Edsa "already midafternoon of Sunday, February 23rd" (Azada and Hermida 109). By that time the Camp was already surrounded by a multitude of people. Karnow described the scene around the Camp thus:

Demonstrators carried banners demanding Marcos's resignation. Rebel soldiers, their flag patches inverted, mingled with the throng. One of several climaxes came when loyalist tanks lumbered into the area. As people chanted hymns, priests and nuns knelt in prayer before the machines, and children pressed flowers on the cries. The tanks retired, the people advanced and the tanks withdrew. The tension continued through the day, the crowd cheering each small victory. The Edsa Revolution subsequently became a legend, encapsulated in Cory's escutcheon: People Power. (428)

The crowd swelled to some two million "people dressed in yellow-singing songs, praying the Rosary, waving yellow flags, and carrying religious statues above their heads" (Azada and Hermida 109). As Time correspondent Roger Rosenblatt recalled, "Try not to forget what you saw last week. You say now that it would be impossible to forget: Filipinos armed to the teeth with rosaries and flowers, massing in front of tanks, and the tanks stopping, and some of the soldiers who were the 
enemy embracing the people and their flowers... The rich were in the streets with the poor, a whole country up in flowers" (14).

There is a comparatively recent event that must be juxtaposed with the above incident however. On February 26, 2008 at the height of the Senate inquiry into the national broadband scandal, people expected from the Catholic bishops a statement calling for the resignation of then President Gloria Macapagal-Arroyo. When the statement came out, however, there was no such call; accordingly, people were "plainly dismayed" that the bishops refused to join what was the raging clamor of many sectors of society at that time (Olivares-Cunanan A13). The dismay may be explained by the expectation that the Catholic bishops would "take up the activist role that the late Jaime Cardinal Sin had played in past political crises" (David A12). Such expectation is of course borne of the lofty regard that the Catholic Church has gained as a dominant player in the political public sphere of the country.

It should be noted that such dismay is also perplexing. Civil society groups in the Philippines have long been known for their dynamism. These groups have multiplied, over the last four decades or so, to an extent unmatched by any other Southeast Asian nation. And yet they seem inadequate on their own to bring about political changes in the country. They appear unable to muster enough influence and social clout to be able to lead the march towards the deepening of democracy and its processes in Philippine society. At present it looks as though political changes in the country still have to count on dominant forces in the public sphere like the Catholic hierarchy.

The positive accommodation accorded to the Catholic Church appears confined to when it serves as a catalyst of a popularly desired social or political change however. When the bishops assert what they consider non-negotiable moral principles pertaining to controversial issues like divorce and abortion, they meet stiff opposition and get accused of interfering in democratic processes, intolerance towards pluralism in modern society, and of resisting progress and change. Such was the reception the Catholic hierarchy reaped in connection with its resolute stance against the passage of a reproductive health law.

The bishops issued a pastoral letter expressly rejecting the proposed bill and calling on the Catholic faithful to do the same. Their objection rested on their conviction about the fundamental element that must comprise human or positive law. Their statement explicitly rejected "the non-consideration of moral principles, the bedrock of law, in legislative discussions of bills that are intended for the good of individuals and for the common good" (CBCP, "Choosing Life, Rejecting the RH Bill").

Some supporters of the reproductive health bill, on the contrary, insisted on a singular issue which should take precedence in the debate among lawmakers-and that is "the right of women, men and young people to full information on sex and reproduction, and to receive the services and assistance they need to lead happy, safe, productive and reproductive lives" (Jimenez-David, "A New Battleground").

Kritika Kultura 24 (2015): -045 
As to the moral questions that the Church raised, these were dismissed as "arcane issues" over which the "Catholic bishops and their supporters . . can keep up the 'dialogue' until well into the next millennium" (Jimenez-David, "Who Is P-Noy Talking with on RH Bill?"). The clear insinuation was that the moral implication of the proposed reproductive health bill is a marginal consideration. The bill's supporters also branded the objection of the bishops an attempt to undermine what they claimed to be a "growing consensus supporting a rational, humane and truly democratic approach to reproductive health" (Jimenez-David, "On the Road to Passage").

\section{HABERMAS ON THE ELEMENTS OF THE PUBLIC SPHERE}

The divergent reactions to the publicity and activism of the Catholic hierarchy in the Philippine political public sphere may appear baffling, but they can be made sense of in light of what Habermas writes about the public sphere and of the participants therein.

It is the irony of modern democracy that instead of empowering all citizens without exclusion-a "government of the people, by the people, and for the people"-it has become a system that excludes the majority of citizens from the system of governance. This exclusionary practice is particularly manifest in the field of legislation. The law in modern democratic states is for the most part positive law, that is to say, enacted and the enactment of laws is carried out by specialized bodies or designated agencies like the parliament or legislature (Rehg 309). This practice assigns the task of lawmaking in the hands of technocrats and expertsan anachronism in a society which is supposed to be distinguished precisely by the democratic genealogy of its law. The result is the "political alienation of great portions of the population from their political representatives" (Preuss 326).

There are other problems that afflict the well-established democratic regimes and exert tremendous strain on their constitutional systems. One version of the strain is evident in the regimes within the Asian geographical region where the democratic model has at times been disparaged because of its alleged failure to improve the economic condition of the state and the people. The success of "high-growth economic policies" pursued under systems that restricted political freedoms had convinced some Asian leaders that "high economic growth confer[s] legitimacy" and is thus "invoked as a rationale for limiting democracy" (Funston 422).

In the face of the above complications, the startling irony is that most people have not given up on democracy. Larry Diamond reveals how people even in very poor nations still pin their hopes for political change in the democratic process: "Connected by grass-roots movements, community radios, cell phones, civic organization, and the Internet, citizens are rising up as never before to challenge corruption, defend the electoral process, and demand better governance" (47).

Kritika Kultura 24 (2015): -045 
The continuing faith in democracy as an "explosive force... in shaping modern legal institutions" (Rasmussen 21$)^{4}$ led Habermas to ask whether democracy is still possible in the context of the modern society. This is what he sought to answer in his comprehensive theory of law and democracy. One of his proposals is to promote thoughtful citizen interaction and opinion-formation to enhance the process of civic discourse and political decision-making. The proposal hinges on his argument that in modernity the rule of law and democracy are internally related, in the sense that only upon its democratic genesis can the law rest its claim to legitimacy.

Habermas thus elaborates a template of how power must circulate within a constitutionally established democratic network based on a model which locates a center-periphery axis within the communicative and decision-making processes of constitutional systems. In the center are the formal branches of government. The periphery is composed of customers and suppliers. Habermas identifies the customers with "complex networks . . . among public agencies and private organizations, business associations, labor unions, interest groups," and the suppliers with "groups, associations, and organizations that, before [legislatures] and through the courts, give voice to social problems, make broad demands, articulate public interests or needs, and thus attempt to influence the political process more from the normative points of view." He categorizes these opinionforming supplier-associations which "specialize in issues and contributions and are generally designed to generate public influence" as constituents of "the civil-social infrastructure of a public sphere" (Between Facts and Norms 355).

Habermas argues that the direction of communication should be twofold. Binding decisions can be carried out with authority only if they pass through the narrow channels of the central axis; for the legitimacy of decisions, the processes of opinion and will formation in the peripheral axis are indispensable. Interventions from the periphery are therefore crucial to the upholding of the democratic process. The pursuit of the common good is best served when social actors in the periphery undertake these interventions because they constitute the majority of the citizenry. This explains why Habermas anchors the promotion of democracy in the modern society on the active role of civil society in the system and practice of governance. He expects civil society "to bear a good portion of the normative expectations, especially the burden of a normatively expected democratic genesis of law" (461). This has to be so because, as Paul Chevigny puts it, "The tree of deliberative politics has to be kept green by a constant flow from civil society and the public sphere" (313).

The public sphere is the arena where the struggle for political influence transpires not only among those who have already attained such influence-"experienced political leaders and officeholders, established parties, and well-known groups..."but also among those whose reputation and influence originally belong to special public spheres-"for example, the authority of religious leaders, the public visibility of literary figures and artists, the reputation of scientists, and the popularity of 
sports figures and movie stars" (Habermas 362). The latter do not enjoy equal opportunity to exert influence. In their respective attempts to acquire political influence in the general public sphere, however, all of them must equally consort with the same lay public and court its approval. There can be no exception, for as Habermas contends:

The public of citizens must be convinced by comprehensible and broadly interesting contributions to issues it finds relevant. The public audience possesses final authority, because it is constitutive for the internal structure and reproduction of the public sphere, the only place where actors can appear. There can be no public sphere without a public. (364)

To influence the public sphere requires publicity and rationality. No person or group can do so without appearing in the public sphere and without arguments that are sustained by convincing reasons. Some persons or groups may attempt to thwart the requirement of rationality by brandishing other resources like money or pressure but their credibility cannot withstand the glare of publicity. ${ }^{5}$ The public sphere is a communication network and not a concrete structure that can be seized through strategic action by persons or groups with vested interest. If the public sphere is at all mobilized it could have been mobilized only by its own act-the public sphere "reproduces itself out of itself" (Goodman 7).

The above explains in part why at the height of the national broadband scandal people turned to the bishops to lead them in a concerted political action. An editorial of one of leading broadsheets in the country, the Philippine Daily Inquirer, explained it best: "If there's any sector that should have the intellectual sophistication and moral conviction to make clear to the populace what should be done, it should be the Catholic bishops" ("Checkmated Bishops").

It should also be added that in terms of publicity the Catholic bishops do not hesitate to declare their position through statements that are carefully crafted and incisively argued. In their objection against the reproductive health law, for instance, the bishops clarified that legislating over such a complex of issues cannot simply be resolved through the pragmatic discourse alone. The programs and policies envisioned by the bill to arrest the "high rate of infant mortality, maternal deaths, and abortions" include as well questions of "human rights and freedom of conscience." There is a moral issue intertwined with the other vital social issues that the proposed bill seeks to address. This is the reason the bishops publicly articulated in their insistence that the bill also focus on its moral implications ("Choosing Life, Rejecting the RH Bill").

On so many other occasions in the past the bishops were able to articulate clearly and accurately the political problems besetting the nation. There was, for instance, their clarion call on the alarming state of Philippine ecology brought about by the wanton exploitation of natural resources resulting to "eroded hills[,] . . dried up river 
beds[,] . . . extensive destruction of coral reefs and mangrove forests" ("A Pastoral Letter on Ecology").

There were also statements condemning "the killing of innocent people and other violations of human rights" ("The Manipulative Use of Human Rights Violations") and a host of criminalities that plagued Philippine society like "salvaging or liquidation[,] ... intimidation or harassment, [and] the increasing use of force to dominate people" ("Message to the People of God on Terrorism") and the rampant kidnapping of innocent persons coupled with the "demand for ransom money in exchange for the safe return of the victims" ("Pastoral Statement on Kidnapping"). The bishops also released public statements on the reform of the system of taxation in the country ("Pastoral Statement on Taxation and the Expanded Value-Added Tax Law"), the external debt, remittances of Overseas Filipino Workers, and corruption ("Pastoral Exhortation on the Philippine Economy") as well as the demolition of the homes of informal settlers and the provision for adequate housing or low-cost housing for the poor ("A Pastoral Statement on the Homeless").

The above citation is meant not only to underline the active involvement and deep concern of the Catholic hierarchy with the crucial social and political issues in Philippine society but also to illustrate how important it is, as Habermas points out, that the public sphere is able to marshal awareness about social problems, generate public attention, and initiate the search for solutions to these problems. This is because the central axis is sometimes unable to appreciate social problems and their magnitude. The legislature may have a lessened ability for such appreciation because of time constraint in its decision making process, the lack of interest to identify newly emergent problems and much less of the initiative to draw significant focus upon it. The executive can be bogged down in gargantuan administrative concerns whereas the judiciary has to wait for a cause of action before it intervenes. Habermas therefore places the greater burden of problematizing crisis situations or social issues on the periphery.

The last point squares with the crucial function that participants in the public sphere must perform if they are to adequately fulfill their political role in society. Habermas understands the public sphere as referring in general to "a communication structure rooted in the lifeworld through the associational network of civil society" that serves, in the particular realm of politics, as "a sounding board for problems that must be processed by the political system because they cannot be solved elsewhere" (Between Facts and Norms 359). It is not the public sphere per se that strives for solutions to social problems, although it can suggest possible remedial actions. What it should primarily do is to ferret out the problems of society, thematize them effectively, and then demand the attention of the government. In this task the Catholic Church as a part of the political public sphere can be said to have acquitted itself creditably.

There is also an element in the public sphere which the Catholic hierarchy can embody with far more determination than other participants in the Philippine public sphere. The democratic procedures that make possible the inputs from 
the public sphere to enlighten and influence the lawmaking process represent the backbone of popular sovereignty in modern society. It is important therefore that the public sphere is able to remain autonomous of and impervious to the machinations of the state. A good number of bishops, and their conference as a body, have maintained their political independence. This is not true for all however as the case of some bishops illustrates. The furor over their receipt of luxury vehicles from the Philippine Charity Sweepstakes Office during the presidency of Macapagal-Arroyo "indicates that even the so-called moral leaders of this nation are not immune to misplacing their ethical bearings-if need be" ("Still Clueless"). Their indiscretion and blunder have seriously dented the credibility of the Catholic Church. As an editorial scathingly castigated, "At a time when the nation needed the moral strength and clarity of the Church as the Arroyo administration lurched from one outrageous impropriety to the next, where were its bishops? Being wined and dined, it now appears - showered with largesse, gifted with SUVs, comfortably set up in what would be called the "Malacañang diocese"" ("Still Clueless").

Habermas adds that "the political sphere can fulfill its function only insofar as it develops out of the communication taking place among those who are potentially affected. It is carried by a public recruited from the entire citizenry" (365). Indeed, it must be stated that this is the proper function of the political sphere, namely, "to secure the protection and integrity of the private sphere" (Goode 9). On this matter two points need to be raised. On the one hand, the reason why the Church has been a major sector of Philippine society is that it represents-and can therefore expect its stand on social and political issues to be supported by-a significant number of the citizenry. On the other hand, when the Church speaks out it is often the lone voice of the hierarchy claiming "monopoly on defining key aspects of the faith" (Racelis A13). This has alienated many Catholics especially by its pronouncement on the reproductive health law. As the social anthropologist, Mary Racelis, wrote, "[I]n our Church, power, obedience, unity, and authoritarian control still rule the day. Increasingly disillusioned laity, devoted to their faith, seek not imperious directives but open, reflective dialogue around revitalized reflection and actionthis as they strive to integrate their continuing discernment of Filipino Catholic spirituality into Christ's teachings" (A13).

The long delayed passage of the reproductive health law in the country caused principally by the sustained and vehement resistance of the Catholic bishops exposes a character of the Church as a part of the public sphere that could be considered as injurious to the consolidation of democracy and inhibitory of the attainment of a public consensus on certain political issues and programs. Habermas has always rejected a concept of democracy based on social power or the factual ability to promote certain interests to the detriment of others. His principal objection is that social power is not normatively constituted. It can disrupt and allow, even as it can also facilitate, the formation of legitimate consensus (Weigard and Eriksen 172).

Kritika Kultura 24 (2015): -045

(C) Ateneo de Manila University

<http://kritikakultura.ateneo.net> 
The Catholic Church definitely wields social power. The influence that it seeks in the political as in all other areas of life is its avowed mission as an institution. It can wield its power by participating as one among other members of the public sphere, in a contest of public acceptance of its position by way of the "compelling force of the better argument based on the relevant information" (Between Facts and Norms 103), or it can unduly assert its influence over individual political leaders and derail the democratic process.

Habermas observes that the official circulation of power in many democracies can be contravened by unofficial currents of power. This contravention can be perpetrated by social power groups like the Catholic Church. When that happens, the potential of democracy to "confront the economically and socially produced destitution, the breakup of solidarity and uprootedness" (Discourse Theory and Its Context 42) as well as its promise to guarantee the equal rights of all citizens, is seriously imperiled. Such contravention can be prevented by restraint on the part of the Church through "a prudent recognition of the limits of [its] authority" (David A12) and a respect for democratic pluralism and process. She must admit that the legitimacy of modern law is no longer to be maintained through authority sustained by either tradition or religious institution. Modern law is not solely dependent on morality moreover. There are many other factors that contribute to the lawmaking process; indeed, "legal norms are premised not only on moral reasons, but also utilitarian considerations, collective values such as the balancing of interests as well as compromises between power constellations" (Weigard and Eriksen 139). As Habermas elucidates further, the claim to legitimacy of modern law rests solely on both its lawful enactment (facticity) and discursive provenance (validity). ${ }^{6}$ Modern law is legitimate to the extent that it is the outcome of a procedure that is democratic. Only with such legitimacy can modern law wield the capacity to achieve its role of integrating society.

The other remedy is for the other members of the public sphere and the citizenry at large to prevent the colonization of the public sphere by a social power be it of the Catholic Church or any other group for that matter. Although the public sphere is primarily a counterpoint to the illegitimate use of power by the state, it should also be a safeguard against members of the public sphere that assert their social power to use the same sphere to advance exclusively their agenda and interests.

Democracy rests on a deliberative politics which consists in an interchange "between democratically institutionalized will-formation and informal opinionformation" (Between Facts and Norms 308). The latter is facilitated by inputs from the public sphere. Social power groups must be resisted because they restrict democracy as they tend to dominate the political process and manipulate it in advancing their private interests.

Kritika Kultura 24 (2015): -045

(C) Ateneo de Manila University

<http://kritikakultura.ateneo.net> 


\section{PROPOSAL FOR A MORE INCLUSIVE CHURCH HIERARCHY}

The activism of the Catholic hierarchy in the Philippine political public sphere can be viewed from two angles. With good reason the people should look up to the bishops' leadership because of their political influence which, as the history of this country attests to, can be wielded as a form of social power to hasten political change.

So pervasive is the influence of the Catholic Church in fact that sometimes people would pass on to Church leaders the social function that they themselves should carry out. The misguided sentiment of many people with respect to the role of the Church in Philippine society is captured in these exact terms by Shirley:

The Church matters, and it matters a great deal. Take it out of Philippine democracy and the democracy will be weakened. Take it out of the society and watch government corruption envelope it. Take it out of the lives of those who believe and their moral compass goes astray. Take the Church out of its oversight and advisory role and the leadership may falter. Finally, take it out of the legitimacy process and the right to rule will be diminished. (178)

The above observation, for the most part and presently true, is also a sad commentary on the Filipinos' level of political maturity. It insinuates that they are ill-equipped to mount political action without the endorsement or patronage of the Church. This situation can only be detrimental to the consolidation and growth of Philippine democracy in the long run. In this connection, there is something very important that the Catholic Church can and must contribute to alter the situation. The statement issued by the Catholic Bishops' Conference of the Philippines ("Seeking the Truth, Restoring Integrity"), while the calls raged for President Arroyo to resign in connection with her alleged complicity in the national broadband project scandal, is a good and politically correct move. In that statement the bishops clarified that their role in society is as pastors and that their statements are not a template for political action. It is a clear acknowledgment and frank declaration of the limited role that the institutional Church plays in a modern democracy. It is also a call for the people themselves to assume their proper function in society.

The clamor of lay people to have their voice heard on the stated position of the Catholic Church on the reproductive health bill should also lead the hierarchy to realize that the Church will be an enriched and not diminished participant in the public sphere if it listens and incorporates into its own the voice of the lay faithful who are, after all, as much an essential part of the Church as the bishops and priests are. 


\section{Notes}

1. This article is an expanded version of the paper entitled "Does Religion Have a Place in the Public Sphere?" presented by the author at the Annual Conference of the Asian Association of Christian Philosophers on "The Rise of the Asian Century: Trends in Asian and Christian Philosophy for Building a Just and Sustainable World," April 11, 2013, Ateneo de Manila University, Quezon City, Philippines.

2. "A month-long Priests' Institute for Social Action conducted in Hong Kong by Fr. Walter Hogan, S.J. in 1965 and attended by a bishop and about thirty priests from the Philippines; the establishment by the Philippine Catholic bishops, in 1966, of a National Secretariat for Social Action (NASSA) headed by the dynamic Bishop Julio Labayen and with a full-time secretariat; and the National Catholic Rural Congress of 1967, which focused attention on the plight of the rural sector" (Carroll 114-115).

3. See also Stanley Karnow, In Our Image: America's Empire in the Philippines (New York: Random House, 1989), 417.

4. In their study of Southeast Asian countries, Clark Neher and Ross Marlay arrive at this conclusion: "As a country modernizes and grows more prosperous, a 'zone of choice' occurs in which more democratic practices are needed to cope with greater social complexity. Higher levels of economic development generally require complex associational and interest groups, educated citizens, entrepreneurial economic classes, and business executives and scientists with a global outlook. All the above are correlated with democratization" (7).

5. Dena Goodman explains this publicity component of the public sphere as follows: "In Habermas's hands, the institutions of bourgeois and Enlightenment sociability become the social structures of the authentic public sphere. It was in these institutions of sociability that private individuals gathered to use their reason and form civil society; it was through the creation of these institutions that they created a new public sphere to challenge and eventually appropriate the old public sphere of the monarchy. For Habermas, the great virtue of these new institutions of sociability was their publicity.... 'The principle of publicity' which underlay these new institutions of sociability came to challenge the practice of secrets of state.' The bourgeois public sphere was authentic precisely because it was open; its true publicity revealed as illegitimate the monarchy's claims to represent the public opaquely, rather than with the new transparency. The veil lay not over the real, hidden, economic interests of the bourgeoisie, but over the political practices of the state" (7).

6. Habermas explains the two elements of modern law. Facticity refers to the social reality of law or its factual enactment, administration, and enforcement in social institutions; validity pertains to the claim of reason, subject to the need for redemption if questioned, that the law deserves general acceptance. There exists a tension between these two elements. William Rehg illustrates the distinction: "Consider, for example, compulsory laws backed by sanctions. 
On the one hand, such laws appear as the will of a lawgiver with the power to punish those who do not comply; to the extent that they are actually enforced and followed, they have an existence somewhat akin to social facts. On the other hand, compulsory laws are not simply commands backed by threats but embody a claim to legitimacy.... At least some portion of a population, indeed the majority, must look at legal rules as standards that everyone ought to follow, whether because they reflect the ways of ancestors, the structure of the cosmos or the will of God or because they have been democratically approved or simply enacted according to established procedures. ... Law is a system of coercive rules and impersonal procedures that also involves an appeal to reasons that all citizens should, at least ideally, find acceptable" (295). 


\section{Works Cited}

Azada, Rowena, and Ranilo Hermida. 'People Power' Revolution: Perspectives from Hannah Arendt and Jürgen Habermas." Budhi: A Journal of Ideas and Culture 5.1 (2001): 85-149. Print.

Burton, Sandra. Impossible Dream: The Marcoses, the Aquinos, and the Unfinished Revolution. New York: Warner, 1989. Print.

Carroll, John J., S.J. "Philippine NGOs Confront Urban Poverty." Organizingfor Democracy: Non-Governmental Organizations, Civil Society, and the Philippine State. Ed. G. Sidney Silliman and Lela Garner Noble. Honolulu: U of Hawaii P, 1998: 113-137. Print.

Catholics Bishops' Conference of the Philippines. "Message to the People of God on Terrorism." 8 July 1985. Web. 30 Dec. 2014.

--.. "Post-Election Statement." 13 Feb. 1986.

--. "The Manipulative Use of Human Rights Violations." 11 July 1989. Web. 30 Dec. 2014.

--.. "Pastoral Statement on Kidnapping." 25 Jan. 1993. Web. 30 Dec. 2014.

--. "Pastoral Statement on Taxation and the Expanded Value-Added Tax Law." 10 July 1994. Web. 30 Dec. 2014.

--.. "Pastoral Statement on the Homeless." 10 July 1997. Web. 30 Dec. 2014.

--. "A Pastoral Letter on Ecology." 29 Jan. 1988. Web. 30 Dec. 2014.

--.. "Pastoral Exhortation on the Philippine Economy." 10 July 1998. Web. 30 Dec. 2014.

--. "Seeking the Truth, Restoring Integrity." 26 Feb. 2008. Web. 30 Dec. 2014.

--. "Choosing Life, Rejecting the RH Bill." 30 Jan. 2011. Web. 30 Dec. 2014.

"Checkmated Bishops." Philippine Daily Inquirer. 15 Feb. 2008: A14. Print.

Chevigny, Paul. "Law and Politics in 'Between Facts and Norms." Perspectives on Habermas. Ed. Lewis Edwin Hahn. Chicago: Open Court, 2002: 309-322. Print.

Clarke, Gerard. "People Power? Non-Governmental Organizations and Philippine Politics since 1986." Philippine Quarterly of Culture E Society 21 (1993): 231-256. Print.

David, Randy. "Should Bishops Lead Political Action?" Philippine Daily Inquirer. 16 Feb. 2008: A12. Print.

Diamond, Larry. "The Democratic Rollback: The Resurgence of the Predatory State." Foreign Affairs 87.2 (2008): 36-48. Print.

Dreyer, Jaco S., and Hennie J.C. Pieterse. "Religion in the Public Sphere: What Can Public Theology Learn from Habermas's Latest Work?” Theological Studies 66.1 (2010): 1-7. Print.

Funston, John, ed. Government and Politics in Southeast Asia. Singapore: Institute of Southeast Asian Studies, 2001. Print.

Goode, Luke. Jürgen Habermas: Democracy and the Public Sphere. London: Pluto, 2005. Print.

Goodman, Dena. "Public Sphere and Private Life: Toward a Synthesis of Current Historiographical Approaches to the Old Regime." History and Theory 31.1 (1992): 1-20. Print. 
Habermas, Jürgen. Between Facts and Norms: Contribution to a Discourse Theory of Law and Democracy. Trans. William Rehg. Cambridge: MIT P, 1996. Print.

--.. "Discourse Theory and Its Context: Democratic Rechtsstaat of Law, Reform Movement and Cultural Diversity in East Asia - An Interview with Jürgen Habermas by Francisco Budi Hardiman." Humanitas Asiatica 1.1 (2000): 39-46. Print.

--. Between Naturalism and Religion. Trans. Ciaran Cronin. Cambridge: Polity _, 2008. Print.

Jimenez-David, Rina. "Who Is P-Noy Talking with on RH Bill?” Philippine Daily Inquirer. 9 Jan. 2011: A11. Print.

--.. "On the Road to Passage." Philippine Daily Inquirer. 1 Feb. 2011: A11. Print.

--.. "A New Battleground." Philippine Daily Inquirer. 2 Feb. 2011: A15. Print.

Karnow, Stanley. In Our Image: America's Empire in the Philippines. New York: Random House, 1989. Print.

Komisar, Lucy. Corazon Aquino: The Story of a Revolution. New York: George Braziller, 1987. Print.

Neher, Clark, and Ross Marlay. Democracy and Development in Southeast Asia. Oxford:

Westview P, 1995. Print.

Olivares-Cunanan, Belinda. "Bishops as Society's Ballast." Philippine Daily Inquirer. 28 Feb. 2008: A13. Print.

Portier, Philippe. "Religion and Democracy in the Thought of Jürgen Habermas." Culture and Society 48 (2011): 426-432. Print.

Preuss, Ulrich K. "Communicative Power and the Concept of Law." Habermas on Law and Democracy: Critical Exchanges. Ed. Michel Rosenfeld and Andrew Arato. Berkeley: U of California P, 1998: 323-335. Print.

Racelis, Mary. "A Listening Church?" Philippine Daily Inquirer. 3 July 2012: A13. Print.

Rasmussen, David. "How Is Valid Law Possible?" Philosophy E Social Criticism 20.4 (1994): 21-44. Print.

Rehg, William. "Habermas's Discourse Theory of Law and Democracy: An Overview of the Argument." Jürgen Habermas II. Ed. David Rasmussen and James Swindal. London: Sage, 2002: 293-315. Print.

Rosenblatt, Roger. "People Power: Corazon Aquino's Forces Take Over in the Philippines," Time 1o Mar. 1986: 14-15. Print.

Shirley, Steven. Guided by God: The Legacy of the Catholic Church in Philippine Politics. Singapore: Marshall Cavendish, 2004. Print.

"Still Clueless." Philippine Daily Inquirer. 9 July 2011: A12. Print.

Weigard, Jarle, and Erik Eriksen. Understanding Habermas: Communicative Action and Deliberative Democracy. London: Continuum, 2003. Print. 
Kritika Kultura 24 (2015): -045

(c) Ateneo de Manila University

<http://kritikakultura.ateneo.net> 